Sacred Springs and Liminal Rivers : Water and Prophecy in the Ancient Eastern Mediterranean

\author{
Nissinen, Martti \\ de Gruyter \\ 2014
}

Nissinen, M 2014 , Sacred Springs and Liminal Rivers : Water and Prophecy in the Ancient Eastern Mediterranean . in E Ben Zvi \& C Levin (eds), Thinking of Water in the Early

Second Temple Period. Beihefte zur Zeitschrift für die alttestamentliche Wissenschaft, vol. pÿ461, de Gruyter , Berlin , pp. 2948 .

http://hdl.handle.net/10138/325483

publishedVersion

Downloaded from Helda, University of Helsinki institutional repository.

This is an electronic reprint of the original article.

This reprint may differ from the original in pagination and typographic detail.

Please cite the original version. 


\title{
Sacred Springs and Liminal Rivers: Water and Prophecy in the Ancient Eastern Mediterranean
}

\author{
MARTTI NISSINEN
}

Water is the absolute precondition for the existence of everything that grows, breaths, and moves. Every living creature is dependent on water, not only to sustain living organisms, but also for other important functions, such as cleaning and transportation. At the same time, water-not just the lack of water but water itself-may also bring about death, since all breathing creatures may drown in it, and flooding water may destroy the same life it has upheld and (re)generated. ${ }^{1}$

According to Thales of Miletos, the pre-Socratic Greek Philosopher, water was the first principle, generator, and nourisher of all things. ${ }^{2}$ Thales's view may have been influenced not only by everyday experience, but also by the idea of the divine power of water - an idea "ubiquitous in religious history." 3 Being the source of both life and death, it is no wonder that divine attributes were given to water. Since water has an "infinitely mutable and thereby unpredictable" quality, ${ }^{4}$ it was understood as the site and medium of supernatural agency. Consequently, water is often connected to magical, medical, and divinatory prac-

1 For the significance of water to human culture in general, see Veronica Strang, The Meaning of Water (Oxford: Berg, 2004).

2 Aristotle, Metaphysics 1.3, 983b; cf. Diogenes Laertius 1.27. See Othmar Keel, "Altägyptische und biblische Weltbilder, die Anfänge der vorsokratischen Philosophie und das 'Aøxท́-Problem in späten biblischen Schriften," in Das biblische Weltbild und seine altorientalischen Kontexte (ed. Bernd Janowski and Beate Ego; FAT 32; Tübingen: Mohr Siebeck, 2001), 27-63, esp. 36-40; Mark Munn, "Earth and Water: The Foundations of Sovereignty in Ancient Thought," in The Nature and Function of Water, Baths, Bathing and Hygiene from Antiquity through Renaissance (ed. Cynthia Kosso and Anne Scott; Technology and Change in History 11; Leiden: Brill, 2009), 191-210, esp. 206.

3 Strang, The Meaning of Water, 85.

4 Rabun Taylor, "River Raptures: Containment and Control of Water in Greek and Roman Constructions of Identity," in The Nature and Function of Water, Baths, Bathing and Hygiene from Antiquity through Renaissance (ed. Cynthia Kosso and Anne Scott; Technology and Change in History 11; Leiden: Brill, 2009), 21-42, esp. 30. 
tices. ${ }^{5}$ Even in prophecy, as this essay attempts to demonstrate, water occasionally features either as part of the oracular process, or as an ingredient of the prophetic message.

All three aforementioned qualities of water-that is: (1) the source of life and purity; (2) a medium for practical functions and supernatural agency; and (3) a destructive power-can be found in Mesopotamian, biblical, and Greek prophetic sources, albeit in different proportions depending on the nature of the source material. In the following essay, I will not refer to every single case in which water is mentioned in these source materials, but will focus on these three recurring topics.

\section{Water as Source of Life and Purity}

Water, for understandable reasons, is used globally as a metaphor for life, probably without any notable culture-specificity. For equally understandable reasons, in many contexts, including the prophetic ones, the life-giving quality of water is attributed to supernatural agency, if not presented as having a divine substance itself. This is the case in the book of Jeremiah, where God is presented as "the fountain of living water" (Jer 2:13; 17:13); this sounds like an apotheosis of the "fountain of life" that is found in Proverbs and Psalms (Ps 36:10; Prov 10:11; 13:14; 14:27; 16:22; cf. the "fountain of wisdom" Prov 18:4). The connotation of the 'living' water (mayim hayyim) is twofold: it combines the life-giving quality of water with its evolution from a natural source, as opposed to the still-standing water of an artificial cistern (Jer 2:13). ${ }^{6}$ In Jer 17:13, forsaking God, the fountain of living water, is equated with death: "O hope of Israel! O Lord! All who forsake you shall be put to shame; those who turn away from you shall be recorded in the underworld, for they have forsaken the fountain of living water, the Lord."

5 See, e.g., Taylor, "River Raptures," 30-31; Yiğit Erbil and Alice Mouton, "Water in Ancient Anatolian Religions: An Archaeological and Philological Inquiry on the Hittite Evidence," JNES 71 (2012): 53-74; Sarah Iles Johnston, Ancient Greek Divination (Blackwell Ancient Religions; Chichester: Wiley-Blackwell, 2008), 98-99; Ann Jeffers, Magic and Divination in Ancient Palestine and Syria (SHCANE 8; Leiden: Brill, 1996), 160-66; M. J. Geller, "West Meets East: Early Greek and Babylonian Diagnosis," in Magic and Rationality in Ancient Near Eastern and Graeco-Roman Medicine (ed. Herman F. J. Horstmanshoff, Marten Stol, and C. R. Van Tilburg; Studies in Ancient Medicine 27; Leiden: Brill, 2004), 24-25, 47-48, 51-52.

6 Cf. Siegfried Herrmann, Jeremia (BKAT 12/2; Neukirchen-Vluyn: Neukirchener Verlag, 1990), 127-28. 
The source of the living water is frequently located in the temple of Jerusalem (or the city of Jerusalem, which amounts to the same thing). Ps 46:5 reads: "There is a river whose streams make glad the city of God, the holy habitation of the Most High." This contrafactual image turns Jerusalem into a mythological fortress and paradise, in the midst of the chaos of roaring waters, trembling mountains, and raging nations. ${ }^{7}$ The image is reinforced in Ezekiel's temple vision in Ezek 47, in which water runs from below the threshold of the entrance to the temple, growing into a mighty stream that flows to every part of the land, nourishing trees that bear fresh fruit every month, "because the water for them flows from the sanctuary" (v. 12). ${ }^{8}$ The water coming forth from the temple also becomes the source of eschatological prosperity in Joel 3:18 and Zech 14:8, ${ }^{9}$ not to forget the book of Revelation, in which John is shown "the river of the water of life, bright as crystal, flowing from the throne of God and of the Lamb" (Rev 22:1). Between the branches of this river the tree of life grows (v. 2), turning the city into a paradise, a topic widely elaborated in apocalyptic literature. ${ }^{10}$

An interesting offshoot of this idea of the river flowing from a divine source can be found in the book of Ben Sira, in which Ben Sira identifies himself as a teacher, and as a rivulet from the stream of Lady Wisdom in Sir 24:30-34: "As for me, I was like a canal from a river, like a water channel into a garden. I said, 'I will water my garden and drench my flower-beds.' And lo, my canal became a river, and my river a sea. I will again make instruction shine forth like the dawn, and I will make it clear from far away. I will again pour out teaching like prophecy, and leave it to all future generations." This is, without doubt, the closest association made between prophecy and water in early Hellenistic Jewish literature, making the "source of the living water" also the source of prophecy, and turning water into a metaphor of wisdom and

7 See Beate Ego, “Die Wasser der Gottesstadt: Zu einem Motiv der Zionstradition und seinen kosmologischen Implikationen," in Das biblische Weltbild und seine altorientalischen Kontexte (ed. Bernd Janowski and Beate Ego; FAT 32; Tübingen: Mohr Siebeck, 2001), 361-89, esp. 363-69. Already Philo (Somn. 2:246) takes it for granted that "the writer here means, figuratively, to speak of some other city than the visible city of God."

8 Cf. Daniel Bodi, "The Double Current and the Tree of Healing in Ezekiel 47:1-12 in Light of Babylonian Iconography and Texts," (paper presented at the annual meeting of the Society of Biblical Literature, Chicago, Ill., 17 November 2012).

9 For a comparison of Ezek 47, Joel 3:18, and Zech 14:8, see Carol L. Meyers and Eric M. Meyers, Zechariah 9-14: A New Translation with Introduction and Commentary (AB 25C; New York: Doubleday, 1993), 435-36.

10 See David E. Aune, Revelation 17-22 (WBC 52C; Nashville: Thomas Nelson, 1998), 1175-78 for an abundance of references. 
the Torah. ${ }^{11}$ The water channel, once again, represents the teacherprophet whose instruction is presented as watering the garden, that is, the people attentive to his teaching.

Forsaking the only source of the living water implies worshiping other deities, which implies impurity, at least in texts with a cultic concern. This highlights another globally known quality of water: its healing and cleansing power, which can be seen as a corollary to its lifegiving capacity. ${ }^{12}$ In Ezekiel, the restoration of the people of Israel also means their purification: "I will sprinkle clean water upon you, and you shall be clean from all your uncleannesses, and from all your idols I will cleanse you" (Ezek 36:25). In Zech 13:1, the eschatological day of salvation brings about the purification of the people: "On that day a fountain shall be opened for the house of David and the inhabitants of Jerusalem, to cleanse them from sin and impurity."

Ritual purity of priests and other cultic functionaries was of paramount importance everywhere in the ancient Eastern Mediterranean. Divination was commonly considered a ritual act, and therefore purity was required of diviners in Mesopotamia ${ }^{13}$ as well as in Greece. ${ }^{14}$ In biblical and Mesopotamian sources, however, the status of the prophets in terms of purity remains unclear. Prophetic performances do not seem to have been regarded as ritual acts in the Near East, and there are no records of purification practices preceding them; one NeoAssyrian letter reports a prophetic performance before the bit rimki rituals performed to the substitute king in Akkad, ${ }^{15}$ but this says nothing

11 Cf. Pancratius C. Beentjes, "What about Apocalypticism in the Book of Ben Sira," in Congress Volume Helsinki 2010 (ed. Martti Nissinen; VTSup 148; Leiden: Brill, 2012), 207-27, esp. 221-23; Benjamin G. Wright, "Conflicted Boundaries: Ben Sira, Sage and Seer," ibid., 229-53, esp. 234-38; Martti Nissinen, "Wisdom as Mediatrix in Sirach 24: Ben Sira, Love Lyrics, and Prophecy," in Of God(s), Trees, Kings, and Scholars: NeoAssyrian and Related Studies in Honour of Simo Parpola (ed. Mikko Luukko, Saana Svärd, and Raija Mattila; StOr 106; Helsinki: Finnish Oriental Society 2009), 377-90.

12 See Jonathan David Lawrence, Washing in Water: Trajectories of Ritual Bathing in the Hebrew Bible and Second Temple Literature (Society of Biblical Literature Academia Biblica; Atlanta: Society of Biblical Literature, 2006).

13 See Michaël Guichard and Lionel Marti, "Purity in Ancient Mesopotamia: The PaleoBabylonian and Neo-Assyrian Periods," in Purity and the Forming of Religious Traditions in the Ancient Mediterranean World and Ancient Judaism (ed. Christian Frevel and Christophe Nihan; Dynamics in the History of Religion 3; Leiden: Brill, 2013), 47113, esp. 80-81.

14 See Sarah Iles Johnston, Ancient Greek Divination, 119-25; Robert Parker, Miasma: Pollution and Purification in Early Greek Religion (Oxford: Clarendon Press, 1983), 22629.

15 SAA 10 352; for this letter, see Simo Parpola, Letters from Assyrian Scholars to the Kings Esarhaddon and Assurbanipal, Vol. 2: Commentary and Appendices (AOAT 5/2; Kevelaer: 
about the purity of the female prophet in question. In the Hebrew Bible, the so-called calling vision of the prophet Isaiah includes the purification of the prophet's unclean lips, not with water, but by touching his lips with a piece of glowing coal (Isa 6:6-7). The background of this scene was probably the mouth-washing or mouth-opening rituals performed in the ancient Near East, but it is unclear whether it implies a general requirement of a prophets' purity. ${ }^{16}$ The prophet Ezekiel is expressly told by God to cook unclean food as a sign of the impure state of the people exiled from Jerusalem, and he replies by saying that he has never eaten anything unclean (Ezek 4:9-17). This, however, indicates defiling Ezekiel's priestly, rather than prophetic, body. ${ }^{17}$

If the association between prophets and purity remains somewhat faint in Near Eastern texts, Greek sources leave no doubt about the significance of purity in the oracular process, at least when it comes to Delphi and Didyma, the two most significant oracle sites of the Hellenistic Greek world. The Pythia of Delphi, according to Plutarch, had to be unmarried and "virginal," because she served as Apollo's bride; the Pythia's "virginity" does not necessarily have sexual overtones but rather refers to her state of purity and freedom from bodily pollution in the first place. ${ }^{18}$ The Pythia had to undergo ritual preparations for every oracular session. The sources tell of a purifying bath after dawn in the Castalian spring, ${ }^{19}$ maybe also drinking from it. The inquirers of the oracle, too, had to be ritually purified before being brought to the Pythia to receive the word of Apollo, and the priests ensured that the day was auspicious for the consultation by presenting a goat to Apollo and

Butzon \& Bercker and Neukirchen-Vluyn: Neukirchener Verlag, 1983), 270-72; Martti Nissinen, References to Prophecy in Neo-Assyrian Sources (SAAS 7; Helsinki: The Neo-Assyrian Text Corpus Project, 1998), 68-77.

16 Victor Hurowitz, "Isaiah's Impure Lips and Their Purification in the Light of Akkadian Sources," HUCA 60 (1989): 39-89, suggests a background in the Mesopotamian mouth-washing ritual, and Gregory Yuri Glazov, The Bridling of the Tongue and the Opening of the Mouth in Biblical Prophecy (JSOTSup 311; Sheffield: Sheffield Academic Press, 2001), 116-64, in the Egyptian mouth-opening ritual.

17 Thus Jaqcueline E. Lapsley, "Body Piercings: The Priestly Body and the 'Body' of the Temple in Ezekiel," Hebrew Bible and Ancient Israel 1 (2012): 231-45, esp. 236-38; cf. Margaret S. Odell, "You Are What You Eat: Ezekiel and the Scroll," JBL 117 (1998): 229-48, according to whom the symbolic acts in Ezek 1-5 indicate a process duting which Ezekiel "must relinquish or, at least, adapt certain elements of his priestly identity before he can assume the role of a prophet" (p. 248).

18 For the Pythia's sexual abstinence as a matter of ritual purity, see H. W. Parke and D. E. W. Wormell, The Delphic Oracle, Vol. 1: The History (Oxford: Blackwell, 1956), 35; Michael Attyah Flower, The Seer in Ancient Greece (Berkeley: University of California Press, 2008), 224-25; Johnston, Ancient Greek Divination, 42-43.

E.g., scholia on Euripides' Phoenician Maidens. 
sprinkling it with water. If the goat nodded its head, the sign was positive, and the goat was sacrificed..$^{20}$

Also in the temple of Apollo at Didyma, the female prophet prepared herself for the reception of the words of the god..$^{21}$ Iamblichus, the third-century $\mathrm{CE}$ neoplatonist, writes about the bathing and the fasting of the prophetess in preparation for prophesying:22

This is what is shown by the abundance of sacrifices, the established custom of the whole ritual, and everything that is performed with due piety prior to divination: also the baths of the prophetess, her fasting for three whole days, abiding in the innermost sanctuaries, already possessed by light, and rejoicing in it for a long time.

The purifying function of water, thus, played an important role in the workings of the Greek oracle. Sacred springs were not always associated with divinatory power, ${ }^{23}$ but many times they appear as a vector of transmitting divine knowledge. ${ }^{24}$ In the most significant Greek oracle sites they served as the source of not only purity but also divine inspiration, as we shall see in the next chapter.

20 This reconstruction of events is based on Euripides, Ion 93, 419; Phoen. 224; Plutarch, Moralia 3:397a; 3:435b; see also Parke and Wormell, The Delphic Oracle, Vol. 1, 19-45.

21 Cf. Joseph Fontenrose, Didyma: Apollo's Oracle, Cult, and Companions (Berkeley: University of California Press, 1988), 81-82.

22 Iamblichus, De Myst. 3.11 (127:11-13); see Emma C. Clarke, John M. Dillon, and Jacksen P. Hershbell, Iamblichus: De mysteriis: Translated with Introduction and Notes (SBLWGRW 4; Atlanta: SBL, 2003), 148-49.

23 For example, the famous Sacred Spring at Corinth is not known as an oracle site. See Guy D. R. Sanders, "The Sacred Spring: Landscape and Traditions," in Corinth in Context: Comparative Studies on Religion and Society (ed. Steven J. Friesen, Daniel N. Schowalter, and James C. Walters; Leiden: Brill, 2010), 365-89.

24 See, e.g., Walter Burkert, "Olbia and Apollo of Didyma: A New Oracle Text," in Apollo: Origins and Influences (ed. Jon Solomon; Tucson, Ariz.: The University of Arizona Press, 1994), 49-60, esp. 59; Rose Lou Bengisu, "Lydian Mount Karios," in Cybele, Attis and Related Cults: Essays in Memory of M. J. Vermaseren (ed. Eugene N. Lane; RGRW 131; Leiden: Brill, 1996), 1-36, esp. 9-10; Jennifer Larson, Greek Nymphs: Myth, Cult, Lore (Oxford: Oxford University Press, 2001), 11-20. For later times, see Gary R. Varner, Sacred Wells: A Study in the History, Meaning, and Mythology of Holy Wells and Waters (2d ed.; New York: Algora Publishing, 2009); James Rattue, The Living Stream: Holy Wells in Historical Context (Woodbridge: Boydell Press, 1995). 


\section{Water as Medium of Divine Agency}

Water is used as a medium of supernatural agency in different kinds of divination, such as the Anatolian ichthyomancy (fish divination) ${ }^{25}$ and the Mesopotamian and Greek lecanomancy (oil divination). ${ }^{26}$ Such media are less common in prophecy, which is essentially a non-technical method of divination. Nevertheless, there is some evidence of water or drink being used as a part of the oracular process, either as a means of triggering the prophets' altered state of consciousness or as a constituent of a ritual act connected to prophesying - or as both, as is the case in Jewish mysticism. In the Hekhalot literature, water not only appears as a ritual precondition for divine revelation, but also as the site where the revelation takes place, and, most notably, as a medium for inducing the altered state of consciousness. ${ }^{27}$ It is quite probable that the medieval Jewish mystics' predilection for water had its roots in the use of water as a medium of divine knowledge in the ancient Eastern Mediterranean.

We have just seen how the Hebrew Bible frequently locates the source of the living water in the temple of Jerusalem. Although in Jerusalem no actual source of water formed part of the architecture of the temple, many Greek sanctuaries were built around a natural well, as is true for some major sites of the Apollonian oracle where the water played a role in the oracular process. This, to be sure, was not the case at Delphi, where the Castalian spring was not located within the sanctuary itself but about $500 \mathrm{~m}$ east of its entrance. The inner sanctum ( $a d y$ ton) of the temple of Apollo at Delphi was built around the "navel of the earth," (omphalos ${ }^{28}$ ), where there was no source of water but there was, allegedly, a chasm exhaling vapors emerging from the ground. The tripod on which the Pythia sat and uttered the words of Apollo

25 See Daniela Lefèvre-Novaro and Alice Mouton, "Aux origins de l'ichthyomancie en Anatolie ancienne: sources archéologiques et textuelles," Anatolica 34 (2008): 7-51.

26 For sources of Mesopotamian lecanomancy, see Giovanni Pettinato, Die Ölwahrsagung bei den Babyloniern (Studi Semitici 21-22; Roma: Istituto di studi del Vicino Oriente, 1966); for Greek and Roman lecanomancy, see Daniel Ogden, Magic, Witchcraft and Ghosts in the Greek and Roman Worlds: A Sourcebook (New York: Oxford University Press, 2002), 39-40; 205-6. Unfortunately, I have not been able to consult the recent study by Netanel Anor, Reading the Oil Omens: A Study of Practice and Record of Mesopotamian Lecanomancy (Jerusalem: Hebrew University, 2010).

27 See Geoffrey W. Dennis, "The Use of Water as a Medium for Altered States of Consciousness in Early Jewish Mysticism: A Cross-Disciplinary Analysis," Anthropology of Consciousness 19 (2008): 84-106.

28 See Julia Kindt, "Omphalos," Encyclopedia of Ancient History (ed. Roger S. Bagnall, et al.; Wiley Blackwell, 2013), 4900-4901. 
was located above the spot where the chasm was believed to produce the vapors that contributed to the altered state of mind of the female prophet. ${ }^{29}$

Unlike Delphi, the other two members of the "big three" locations of Apollonian prophecy, the temples at Didyma and Claros, were both constructed around a water source. At the heart of the temple of Apollo at Didyma there was a very large open-air adyton, within which there was a "little temple" (naiskos), as well as the sacred spring with an archaeologically attested spring chamber built around it. ${ }^{30}$ It was probably a natural water source that had an important function in the oracular sessions which, therefore, took place in the adyton. Iamblichus reports that the female prophet of Didyma wet her feet in the water, probably of the sacred spring, and inhaled its vapors. This, according to him, enabled the prophet to "partake" of Apollo, that is, to become possessed by him:

And as for the woman at Branchidai who gives oracles, it is either by holding the staff first given by a certain god that she is filled by the divine radiance; or else when sitting on the axle she predicts the future; or when dipping her feet or skirt in the water, or inhaling vapour from the water, at any rate, she receives (dekhetai) the god: prepared and made ready by any or all of these preliminaries for his reception from without, she partakes (metalambanei) the god. ${ }^{31}$

Iamblichus' terminology of "receiving" and "partaking" of the god corresponds to his idea of divine possession as a communion with the divine, in which the human consciousness is partly or wholly replaced with the divine consciousness: "For either the god possesses us, or we become wholly the god's property, or we exercise our activity in common with him. And sometimes we share in the god's lowest power, sometimes in his intermediate, and sometimes in his primary power. And sometimes there is a mere participation, sometimes a communion,

29 Thus Plutarch, Moralia 5:433c-d; Diodorus Siculus 16.26.1-6. For the problem of the chasm and the reality of the presence of gases, see John Bowden, Classical Athens and the Delphic Oracle: Divination and Democracy (Cambridge: Cambridge University Press, 2005), 18-19.

30 For the architecture of the temple at Didyma, see Fontenrose, Didyma, 28-44; Klaus Tuchelt, Branchidai-Didyma: Geschichte, Ausgrabung und Wiederentdeckung eines antiken Heiligtums, 1765-1900 (Antike Welt Sondernummer 22 = Zaberns Bildbände zur Archäologie 3; Mainz: von Zabern, 1991); Alan M. Greaves, Miletos: A History (London: Routledge, 2002), 111-17.

31 Iamblichus, De Myst. 3.11 (127:4-9); see Clarke, Dillon, and Hershbell, Iamblichus, $148-49$. 
and sometimes even a union." ${ }^{32}$ Iamblichus relates that even the male prophet of Claros, through similar means as the female prophet of Didyma-fasting, seclusion, and drinking the water from the sacred spring - "has the inspiration of the god illuminating the pure sanctuary of his own soul, and providing for it an unhindered divine possession, and a perfect and unimpeded presence." 33 One could imagine that the communion with the divine took place without the help of any material media, and it is possible that Iamblichus gives a neoplatonic explanation to practices that were known to have existed at these oracle sites. Nevertheless, it deserves attention that Iamblichus also recognized the use of music in inducing the state of possession, the explanation being that "before it gave itself to the body, the soul heard the divine harmony." 34

Even at Claros an underground adyton has been uncovered in excavations, ${ }^{35}$ and ancient writers refer to a sacred spring that played an important role in producing oracles at this site. Iamblichus writes: "It is agreed by everyone that the oracle at Colophon prophesies by means of water. There is a spring in a subterranean chamber, and from it the prophet drinks on certain appointed nights, after performing many preliminary ceremonies, and after drinking, he delivers his oracles, no longer seen by the spectators present. That this water has oracular power is immediately obvious." ${ }^{36}$ Even Pliny knows that "in the cave of Apollo at Claros at Colophon there is a pool, a draught from which causes marvelous oracular utterances to be produced, though the life of the drinkers is shortened." 37 Tacitus relates that the prophet at Claros was an illiterate man: "There, it is not a woman, as at Delphi, but a priest chosen from certain families, generally from Miletus, who ascertains simply the number and the names of the applicants. Then de-

32 Iamblichus, De Myst. 3.5 (111:7-11); see Clarke, Dillon, and Hershbell, Iamblichus, 130-31; Crystal Addey, "Divine Possession and Divination in the Graeco-Roman World: The Evidence from Iamblichus's On the Mysteries," in Spirit Possession and Trance: New Interdisciplinary Perspectives (ed. Bettina E. Schmidt and Lucy Huskinson; London: Continuum, 2010), 171-85.

33 Iamblichus, De Myst. 3.11 (126:1-3); see Clarke, Dillon, and Hershbell, Iamblichus, $146-47$.

34 Iamblichus, De Myst. 3.9 (120:3-10); see Clarke, Dillon, and Hershbell, Iamblichus, 140-41; Addey, "Divine Possession and Divination in the Graeco-Roman World," $177-78$.

35 For the archaeology of Claros, see Juliette de La Genière, "Klaros: Bilan provisoire de dix campaignes de fouilles," REA 100 (1998): 235-56.

36 Iamblichus, De Myst. 3.11 (124:8-12); see Clarke, Dillon, and Hershbell, Iamblichus, 144-147.

37 Pliny, Nat. hist. 2.232. 
scending into a cave and drinking a draught from a secret spring, the man, who is commonly ignorant of letters and of poetry, utters a response in verse answering to the thoughts conceived in the mind of any inquirer." 38 Again, water functions as a medium of divine inspiration and knowledge.

The oracles of Zeus were pronounced in the fourth major oracle site, Dodona, the best-known symbol of which was the sacred oak..$^{39}$ According to some ancient authors, the rustling of the tree's branches and leaves were interpreted by priests called selloi. Later texts name even more sources of prophetic inspiration, for instance, the sounds of Dodona's famous bronze cauldrons; these are associated with the prophetesses' activity by Clement of Alexandria and by Lucan. ${ }^{40}$

Even water is associated with Dodona prophecy in later sources, according to which, the "murmuring" of the spring flowing under the roots of the oak inspired the female prophets to prophesy. ${ }^{41}$ Archaeologically, no such spring has been found at Dodona; rather, the idea of a spring at Dodona is comparable to the inspirational springs at other famous oracle sites, and attests "both to the practice of embroidering great religious sites with additional, remarkable physical characteristics $\ldots$ and to the tendency to transfer the traits of one oracle to another." 42

The most reliable information concerning the connection between the sacred spring and prophecy comes from Didyma and Claros. In both cases, the sacred spring is at the heart of the sanctuary, where prophesying also takes place. The case of Delphi is different because it involves not water but vapors, but the idea is the same, that a substance conveys the divine spirit to the prophet, causing her to reach an altered state of consciousness and, thus, to be able to utter divine words. Even at Delphi, the water of the Castalian spring is necessary in the Pythia's preparations for receiving the divine word.

38 Tacitus, Annales 2.54

39 For the oracle of Dodona, see Esther Eidinow, Oracles, Curses, and Risk among the Ancient Greeks (Oxford: Oxford University Press, 2007); Barbara Kowalzig, Singing for the Gods: Performances of Myth and Ritual in Archaic and Classical Greece (Oxford: Oxford University Press, 2007), 331-52; Johnston, Ancient Greek Divination, 60-72.

40 Clement of Alexandria, Exhortation to the Greeks 2.11; Lucan 6.425.

41 Servius, Commentary on the Aeneid 3.466: circa hoc templum quercus inmanis fuisse dicitur, ex cuius radicibus fons manabat, qui suo murmure instinctu deorum diversis oracula reddebat: quae murmura anus Pelias nomine interpretata hominibus disserebat. Cf. Pliny, Nat. Hist. 2.228.

42 Johnston, Ancient Greek Divination, 66. For the archaeology of Dodona, see Martina Dieterle, Dodona: Religionsgeschichtliche und historische Untersuchungen zur Entstehung und Entwicklung des Zeus-Heiligtums (Spudasmata 116; Hildesheim: Olms, 2007). 
This kind of association of water and prophecy is known neither in the Hebrew Bible nor in any other ancient Near Eastern source. Nothing in these sources suggests that the "living water" available at temples ever played a role in the prophetic process of communication. This may partly be due to our lack of knowledge about how the oracular process in the Near East actually worked, but one should also note that Mesopotamian temples were not constructed around natural springs with which the prophetic activity inside could have been connected; the same can be said of the temple of Jerusalem, whose association with water belongs to an eschatological reality (see above).

There is one letter from Mari, though, suggesting that prophetic inspiration could have been triggered by means of drinking a liquid of some kind: 43

Concerning the campaign my lord is planning, I gave drink to male and female persons to inquire about signs. ${ }^{44}$ The oracle is extremely favorable to my lord. Likewise, I inquired of male and female persons about Išme-Dagan. The oracle is unfavorable to him.

The one writing to King Zimri-Lim here is Queen Šibtu, who, even in another letter ${ }^{45}$ reports using the same divinatory technique, which is as obscure as it is interesting. Šibtu does not explicate what kind of drink she provided the male and female persons with, or how and why it facilitated the oracular process; in fact, she only mentions the act of giving drink, not the liquid itself. In any case, the men and women in

43 ARM 26207 (= SBLWAW 12 17): 3-11; for interpretations of this text, see Jean-Marie Durand, "In vino veritas," RA 76 (1982): 43-50; Claus Wilcke, "ittätim ašqi aštāl: Medien in Mari?," RA 77 (1983): 93; Jack M. Sasson, "The Posting of Letters with Divine Messages," in Florilegium Marianum II: Recueil d'études à la mémoire de Maurice Birot (ed. Dominique Charpin and Jean-Marie Durand; Mémoires de NABU 3; Paris: SEPOA, 1994), 299-316, esp. 307-8; Martti Nissinen, "Prophetic Madness: Prophecy and Ecstasy in the Ancient Near East and in Greece," in Raising Up a Faithful Exegete: Essays in Honor of Richard D. Nelson (ed. K. L. Noll and Brooks Schramm; Winona Lake, Ind.: Eisenbrauns, 2010), 3-29, esp. 15-16; Dominique Charpin, “Le prophétisme d'après les archives de Mari (xviiie siècle av. J.-C.)," in Les recueils prophétiques de la Bible: Origines, milieux, et contexts proche-oriental (ed. Jean-Daniel Macchi, et al.; Le monde de la Bible 64; Geneva: Labor et fides, 2012), 31-73, esp. 65; Jonathan Stökl, Prophecy in the Ancient Near East: A Philological and Sociological Comparison (CHANE 56; Leiden: Brill, 2012), 49-50.

44 This translation of the Akkadian phrase ittātim zikāram u šinništam ašqi interprets the male and female persons themselves as signs in the same way a prophet appears in the Epic of Zimri-Lim (SBLWAW 12 64), line 139: "The hero of the land saw his sign, the prophet" (see Charpin, "Le prophétisme d'après les archives de Mari," 65). Sasson, "The Posting of Letters with Divine Messages," 308 translates "I gave male and female the signs to drink," assuming that the drink contains the signs to be interpreted.

ARM 26212 (= SBLWAW 12 22): 1-2. 
question are prompted, by drinking, to utter the inquired oracles. It seems that this method of soliciting oracles was somewhat unusual, since Šibtu anticipated an accusation that she had obtained the oracle in an inappropriate way: "Perhaps my lord would say this: 'She has made them speak by fraudulent means.'" 46

In another letter from Mari, likewise sent by Queen Šibtu to her royal husband Zimri-Lim, the divine assembly under the leadership of Ea takes an oath by drinking water mixed with dirt taken from the door-jambs of Mari: ${ }^{47}$

Door-jamb dirt from the gate of Mari was brought and dissolved in water. The gods and goddesses drank it and Ea said to the gods: "Stand up, those of you who intend harm to the brickwork of Mari or to the protective guardian [of Mari]!" The gods and the goddesses [said]: "We intend no harm to the brickwork of Mari or to the protective guardian of Mari!"

The historical context of this vision of the prophet Qišti-Diritim, quoted by Šibtu in her letter, is the invasion of the Elamites in Zimri-Lim's tenth regnal year, and it can be read as a prophetic endorsement of his military actions against the Elamites, protecting them under a divine oath.

Another example of the function of water as the medium in oathtaking can be found in the oracle of Ištar of Arbela belonging to the collection of prophecies pronounced at the meal of the covenant, that

ARM 26207 (= SBLWAW 12 17): 35-36.

47 ARM 26208 (= SBLWAW 12 18): r.15-26. For this text, see Christoph Uehlinger, "Audienz in der Götterwelt: Anthropomorphismus und Soziomorphismus in der Ikonographie eines altsyrischen Zylindersiegels," UF 24 (1992): 339-59, esp. 351-52; Jack M. Sasson, "Mari Apocalypticism Revisited," in Immigration and Emigration within the Ancient Near East: Festschrift E. Lipiński (ed. K. van Lerberghe and A. Schoors; OLA 65; Leuven: Peeters, 1995), 285-98, esp. 286-87; Martti Nissinen, "Prophets and the Divine Council," in Kein Land für sich allein: Studien zum Kulturkontakt in Kanaan, Israel/Palästina und Ebirnâri für Manfred Weippert zum 65. Geburtstag (ed. Ulrich Hübner and Ernst Axel Knauf; OBO 186; Fribourg: Universitätsverlag and Göttingen: Vandenhoeck \& Ruprecht, 2002), 4-19, esp. 7-8; Dominique Charpin and Jean-Marie Durand, "Des volontaires contre l'Élam," in Literatur, Politik und Recht in Mesopotamien: Festschrift für Claus Wilcke (ed. Walther Sallaberger, Konrad Volk, and Annette Zgoll; Orientalia Biblical et Christiana 14; Wiesbaden: Harrassowitz, 2003), 63-76, esp. 74-75. 
was served on the terrace of the Ešarra temple at Assur ${ }^{48}$, on the occasion of Esarhaddon's enthronement in in 680 BCE:49

She gave them șarșāru water to drink. She filled a pitcher of one seah with șarșāru water, gave it to them and said: "You say to yourself: 'Ištar - she is small beer!' Then you go into your cities and your districts, eat your own bread and forget this covenant. But every time you drink this water you remember me and keep this covenant which I have made on behalf of Esarhaddon."

The text combines ritual actions with divine words and reads like a scribal compilation describing a ritual and the prophetic oracle pronounced during that ritual..$^{50}$ A specific kind of water, mê șarșāru, serves as a reminder of the covenant. The meaning of the word șarșāru is unclear, ${ }^{51}$ but it is also used in an incantation in which it also belongs to taking an oath by drinking water from șarșāru. ${ }^{52}$

Here it is a prophet of Ištar who mediates divine words concerning the adê being made between the gods of Assyria and the vassal states, as well as between Esarhaddon and the vassal kings as the gods' earthly representatives. The oath is taken by gods and humans alike, the vassal kings participating in the meal of covenant, to which the gods are also invited by Ištar. ${ }^{53}$ The specific water used for the oath-taking apparently functioned as a medium of divine agency, serving as a reminder, but also probably as the activator, of the covenant, hence ful-

48 The terrace of the Ešarra temple is mentioned as the scene of royal rituals in Assur; see Simo Parpola, Assyrian Prophecies (SAA 9; Helsinki: Helsinki University Press, 1997), 25 (ad iii 2); G. van Driel, The Cult of Aššur (SSN 13; Assen: van Gorcum, 1969), 194.

49 SAA 93.4 (= SBLWAW 12 87) iii 3-15. For interpretations of this text, see Parpola, Assyrian Prophecies, XIX-XX; Eckart Otto, Das Deuteronomium: Politische Theologie und Rechtsreform in Juda und Assyrien (BZAW 284; Berlin: de Gruyter, 1999), 80-84; Manfred Weippert, "'König, fürchte dich nicht!': Assyrische Prophetie im 7. Jahrhundert v. Chr.," Or 71 (2002): 1-54, esp. 15-19; Nissinen, "Prophets and the Divine Council," 14-15; Matthijs J. de Jong, Isaiah among the Ancient Near Eastern Prophets: A Comparative Study of the Earliest Stages of the Isaiah Tradition and the Neo-Assyrian Prophecies (VTSup 117; Leiden: Brill, 2007), 409-11; Stökl, Prophecy in the Ancient Near East, 138-40.

50 Cf. de Jong, Isaiah among the Ancient Near Eastern Prophets, 411; Stökl, Prophecy in the Ancient Near East, 140.

51 Parpola, Assyrian Prophecies, 25, associates it with the rabbinic șarșūr, which means a stone vessel used as a cooler (cf. CAD S 115 sub șarșaru B).

52 Šurpu iii 62; see Erica Reiner, Šurpu: A Collection of Sumerian and Akkadian Incantations (AfO Beiheft 11; Osnabrück: Biblio, 1970 [repr. 1956]), 21.

53 The tablet is broken here, but what remains can be read as Ištar's invitation to the

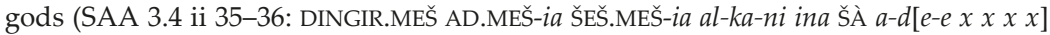
"Come, gods, my fathers and brothers! [Enter] the coven[ant ...]." 
filling a function similar to the wine in Christian eucharist: "Whenever you drink it, do this for the remembrance of me" (cf. Mark 14:24; 1 Cor $11: 25)$.

\section{Water as Destructive Power}

The flipside of the life-giving powers of water is its destructive force. The West Semitic and biblical mythology knows the Sea and the River as rivals and adversaries of benevolent divine powers. ${ }^{54}$ In Ugaritic mythology, the chaotic and destructive aspect of Yam competes with the life-giving aspects of Baal. ${ }^{55}$ Such a combat is even reflected in prophetic literature, for instance, in Hab 3:8: "Was your wrath against the rivers, $\mathrm{O}$ Lord? Or your anger against the rivers, or your rage against the sea, when you drove your horses, your chariots to victory?" In the book of Ezekiel, the oracles against Tyre (Ezekiel 27-28) repeatedly use the expression "in the heart of the seas" (b̆e-lēb yāmîm) for the site of both dominion (27:4) and destruction (27:25-27); the corresponding Akkadian phrase ina qabal tâmtim denotes the utmost end of the horizon and symbolizes the global dominion of the Assyrian king. ${ }^{56}$

Rivers in particular appear as liminal spaces that can bring about destruction as well as the act of salvation, through the crossing of them. The crossings of the Red Sea (Exod 14) and the river Jordan (Josh 3) are foundational events in biblical history, marking a transition from one status to another; the parting of waters by the prophets Elijah and Elisha in $2 \mathrm{Kgs}$ 2:8, 14 is a clear reminiscent of this. Ancient Near Eastern kings, including Alexander the Great, repeatedly recorded crossings of

54 See, e.g., John Day, God's Conflict with the Dragon and the Sea: Echoes of a Canaanite Myth in the Old Testament (UCOP 35; Cambridge: Cambridge University Press, 1985).

55 See Pierre Bordreuil and Dennis Pardee, "Le combat de Ba'lu avec Yammu après les textes ougaritiques," MARI 7 (1993): 63-70; cf. Jean-Marie Durand, "Le mythologème du combat entre le dieu de l'orage at la mer en Mésopotamie," MARI 7 (1993): 41-61.

56 See Martin Lang and Robert Rollinger, "Im Herzen der Meere und in der Mitte des Meeres: Das Buch Ezechiel und die in assyrischer Zeit fassbaren Vorstellungen von den Grenzen der Welt," in Interkulturalität in der Alten Welt: Vorderasien, Hellas, Ägypten und die vielfältigen Ebenen des Kontakts (ed. Robert Rollinger, et al.; Philippika 34; Wiesbaden: Harrassowitz, 2010), 207-64. The expression qabal tâmtim is used by the king of Tyre in Assurbanipal's annals, where he is said to dwell "in the heart of the sea" (Prism B §15 ii 42 and parallels); see Rykle Borger, Beiträge zum Inschriftenwerk Assurbanipals: Die Prismenklassen $A, B, C=K, D, E, F, G, H, J$ und $T$ sowie andere Inschriften (Wiesbaden: Harrassowitz, 1996), 28, 216. 
rivers during their campaigns, presenting them not merely as technical operations, but as acts of royal skill and divine will. ${ }^{57}$

In Neo-Assyrian prophecy, rivers are part of the chaotic wilderness, full of all kinds of liminal spaces, that Ištar ranges through for the sake of the life of Assurbanipal, her beloved king: 58

Desiring your life I roam the steppe, continually crossing rivers and oceans, ranging mountains and alps. Continually crossing all rivers, I am finished off by droughts and showers. My charming figure they ravage; my body is exhausted and troubled for your sake.

This is reminiscent, not only of Gilgameš's roaming of the steppe after the death of Enkidu, but also of Esarhaddon's, Assurbanipal's father's, "roaming in the steppe" 59 while being expatriated during the civil war preceding his ascendance to the throne of Assyria. ${ }^{60}$ Crossing rivers and oceans (nārāti u tâmāti), even "all rivers" (nārāti kalī̌sina), symbolizes the all-encompassing efforts of the goddess to save Assurbanipal's life in the middle of the civil war, and convince the divine council (puhur ilāni) about his kingship. ${ }^{61}$

The river already appears as the site of the enemies' destruction in a letter from Mari, in which the majordomo Sammetar reports the words of the prophet Lupahum: ${ }^{62}$

As before, when the Yaminites came to me and settled in Saggaratum, I was the one who spoke to the king: "Do not make a treaty with the Yaminites! I shall drive the shepherds of their clans away to Hubur (ina hu-

57 See Robert Rollinger, Alexander und die großen Ströme: Die Flußüberquerungen im Lichte altorientalischer Pioniertechniken (Schwimmschläuche, Keleks und Pontonbrücken) (Classica et Orientalia 7; Wiesbaden: Harrassowitz, 2013).

58 SAA 99 (= SBLWAW 12 94): 8-15.

59 Cf. SAA 91.8 (= SBLWAW 12 75) v 12-20: "I am the Lady of Arbela! To the king's mother since you implored me, saying: 'The one on the right and the other on the left you have placed in your lap. My own offspring you expelled to roam the steppe.'" This refers to Esarhaddon's two rebelling brothers.

60 For this text and the allusions to Gilgameš, see Parpola, Assyrian Prophecies, IL-L, 41; de Jong, Isaiah among the Ancient Near Eastern Prophets, 405-8; Charles Halton, "Allusions to the Stream of Tradition in Neo-Assyrian Oracles," ANES 46 (2009): 50-61, esp. 57-58.

61 The tablet is dated to the year 650, when Assurbanipal was waging war against his brother Šamaš-šumu-ukin; see Nissinen, "Prophets and the Divine Council," 12-13. According to de Jong, the text "skillfully ties up the fate of Ashurbanipal and Šamaššum-ukin with that of Gilgameš and Enkidu. The Leitmotif of SAA 99 is the life of Ashurbanipal, which through the Gilgameš-parallel mirrors the death of Šamaššum-ukin" (Isaiah among the Ancient Near Eastern Prophets, 408). 
bu-ur-re-e), and the river will finish them off for you." Now then, he should not pledge himself without consulting God.

As the underworld river, Hubur63 symbolizes the death of the Yaminites, but at the same time, it is also used as a pun on Habur, the tributary of the Euphrates within the area of the kingdom of Mari.64 Lupahum's words present the prophecy concerning the defeat of the Yaminites as a "lesson that Zimri-Lim should be drawing from recent history" 65 in a situation where he has to decide whether to make a treaty with the king of Ešnunna. ${ }^{66}$ The river is mentioned several times in the context of Esarhaddon's civil war and his eventual victory: ${ }^{67}$

Fear not, king! I have spoken to you, I have not slandered you! I have inspired you with confidence, I have not caused you to come to shame! I will lead you safely across the River.

Similarly to the mention of Hubur/Habur in the Mari letter cited above, the prophetic reference to the river is both historical and mythological. The river probably represents mythical allusions ${ }^{68}$, but is also a historical point of reference to Esarhaddon's victory over his brothers before his ascension to the Assyrian throne. ${ }^{69}$ This is what Esarhaddon himself relates in his inscription: ${ }^{70}$

I reached embankment of the Tigris and, upon the command of Sin and Šamaš, the lords of the harbor, I let all my troops jump across the broad river Tigris, as if it were nothing but a ditch.

63 See Hannes D. Galter, “Hubur," DDD² (1999): 430-31.

64 See Dominique Charpin, "Prophètes et rois dans le Proche-Orient amorrite: Nouvelles données, nouvelles perspectives," in Florilegium Marianum VI: Recueil d'études à la mémoire d'André Parrot (ed. Dominique Charpin and Jean-Marie Durand; Mémoires de NABU 4; Paris: SEPOA, 2002), 7-38, esp. 25 n. 149.

65 Jack M. Sasson, "Water beneth Straw: Adventures of a Prophetic Phrase in the Mari Archives," in Solving Riddles and Untying Knots: Biblical, Epigraphic, and Semitic Studies in Honor of Jonas C. Greenfield (ed. Ziony Zevit, Seymour Gitin, and Michael Sokoloff; Winona Lake, Ind.: Eisenbrauns, 1995), 599-608, esp. 603.

66 For the historical circumstances, see Charpin, "Prophètes et rois dans le ProcheOrient amorrite," 22-25.

67 SAA 91.6 (= SBLWAW 12 73) iii 30 - iv 4.

68 For the deification of the river Tigris, see Bendt Alster, "Tigris," $D D D^{2}$ (1999): 870-71.

69 Thus Parpola, Assyrian Prophecies, LXXIII, 8; Nissinen, References to Prophecy in NeoAssyrian Sources, 25. For a different historical interpretation of the oracle SAA 9 1.6, see de Jong, Isaiah among the Ancient Near Eastern Prophets, 267-68, who dates it to the period preceding Esarhaddon's campaign to Egypt in 674 BCE.

70 Esarhaddon 1 (= Nineveh A = SBLWAW 12 97) i 84-86; see Erle Leichty, The Royal Inscriptions of Esarhaddon, King of Assyria (680-669 BC) (RINAP 4; Winona Lake, Ind.: Eisenbrauns, 2011), 14. 
Again, the crossing of the river appears as a divinely ordered act of salvation which is not merely part of a military strategy, but constitutes a transition from one phase to another, in Esarhaddon's case: from the chaotic period of the civil war to the restoration of kingship. The river represents a dangerous liminal space to be traversed before the transition is completed. As in the case of Hubur/Habur in the letter from Mari, the river symbolizes the victory of the king and the destruction of his enemies: ${ }^{71}$

As you were standing in their midst, I removed them from your presence, drove them up the mountain and rained fire and brimstone upon them. I slaughtered your enemies and filled the River with their blood.

The prophetic oracles and the royal inscriptions doubtlessly refer to historical events that accompanied Esarhaddon's rise to power, but both genres do it in a highly mythologized manner. The account of Esarhaddon's war against his brothers is replete with allusions to literary works that depict Ninurta's and Marduk's battles against their enemies (Lugale, Enuma eliš), equating the king to these gods and mythologizing his battles against his enemies. ${ }^{72}$

Finally, the river appears as the site of salvation and destruction in Assurbanipal's inscription about his war against Elam in 653 BCE. The grande finale of this war takes place at the river Ulaya before entering Susa, the Elamite capital: ${ }^{73}$

Upon the command of Aššrur and Marduk, the great gods, my lords, who encouraged me with good omens, dreams, speech omens, and prophetic messages, I defeated them in Tell Tuba. With their bodies I stuffed up Ulaya. With their corpses, as if with thorn and thistle, I filled the outskirts of Susa.

Just as the crossing of the Tigris was the final and decisive ordeal Esarhaddon had to go through before his rise to power, the crossing of Ulaya marks the divinely ordained victory of Assurbanipal over the Elamites. Again, the river brings about salvation to the king and destruction to his enemies. Filling the river with their corpses is an image of total destruction that is also shown in the relief depicting Assurbani-

71 SAA 93.3 (= SBLWAW 12 86) ii 18-23.

72 See Amar Annus, The God Ninurta in the Mythology and Royal Ideology of Ancient Mesopotamia (SAAS 14; Helsinki: The Neo-Assyrian Text Corpus Project, 2002), 100; cf. de Jong, Isaiah among the Ancient Near Eastern Prophets, 259.

73 Prism B v 93-99 (= SBLWAW 12 101). See Borger, Beiträge zum Inschriftenwerk Assurbanipals, 104, 225; for the historical circumstances, see Nissinen, References to Prophecy in Neo-Assyrian Sources, 46-51. 
pal's war against the Elamites (figure). The lower register of the relief, originally belonging to the North Palace of Nineveh, shows the river Ulaya literally stuffed up with the dead bodies of the enemies. ${ }^{74}$

Assurbanipal's relief is a prime example of a performative image that does not simply illustrate the events related in the inscription, as a visual copy of preexisting reality, but creates and renews that reality through the act of representation: "Representation was thought to make things happen, not simply to depict." 75 In fact, this is true not only for the relief but also for the inscription. Both the textual and pictorial media, rather than recording acts of eyewitnessing, carry an authoritative ideological interpretation of the recorded events. ${ }^{76}$

Even the river, whether textual or graphic, has a performative function. It is "real" in the sense that it has a historical and geographical point of reference, but it is also contextualized by the textual/iconographic ideological program. The river retains its mythological value as a liminal space where both salvation and destruction take place, and it is indexical in constantly renewing the permanent meaning of the event in the minds of the audience.

74 For these reliefs and the epigraphs attached to them, see John Malcolm Russell, The Writing on the Wall: Studies in the Architectural Context of Late Assyrian Palace Inscriptions (Mesopotamian Civilizations 9; Winona Lake, Ind.: Eisenbrauns, 1999), 156-99; Zainab Bahrani, Rituals of War: The Body and Violence in Mesopotamia (New York: Zone Books, 2008), 23-55.

75 Bahrani, Rituals of War, 53.

76 See Christoph Uehlinger, "Neither Eyewitnesses, Nor Windows to the Past, but Valuable Testimony in its Own Right: Remarks on Iconography, Source Criticism and Ancient Data-Processing," in Understanding the History of Ancient Israel (ed. H. G. M. Williamson; Proceedings of the British Academy 143; Oxford: Oxford University Press, 2007), 173-228. 


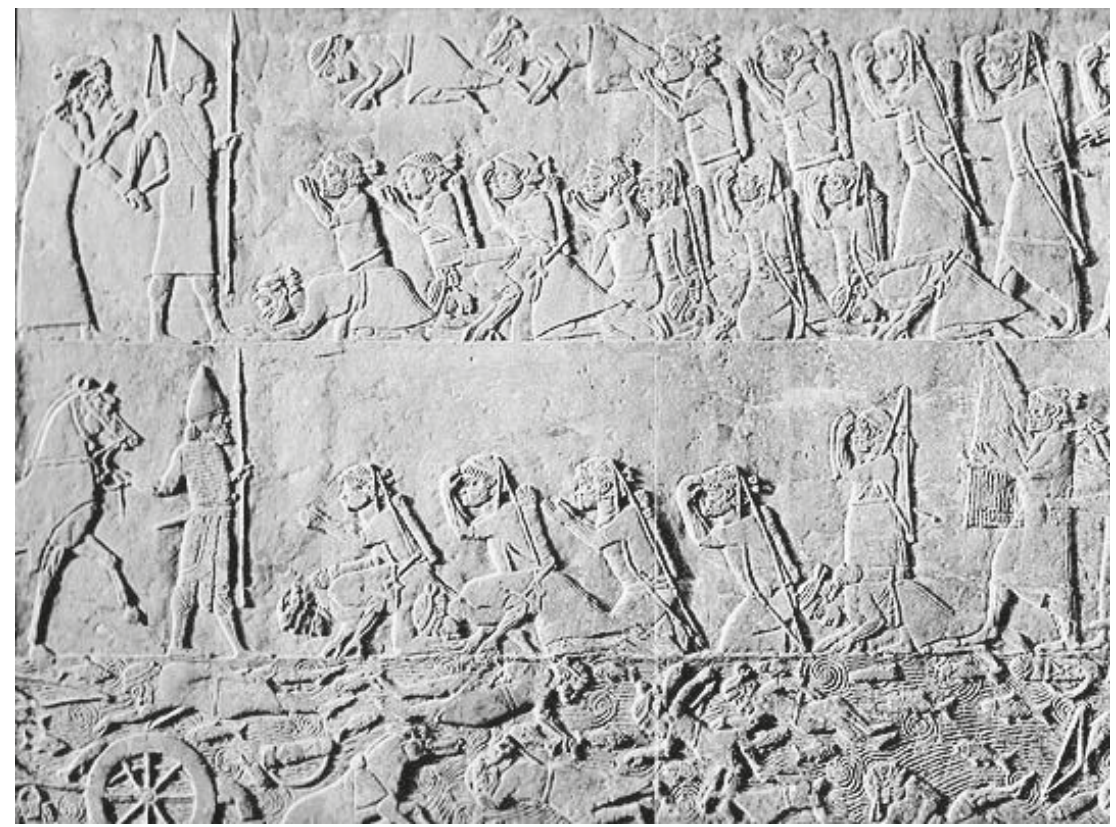

Assurbanipal's war against the Elamites

\section{Conclusion}

The significance of water for prophecy reveals itself in manifold ways in ancient Eastern Mediterranean prophetic texts and practices. As the source of life, water can be equated with a benevolent deity. It can also be seen as a metaphor for, or manifestation of, divine favor. As a medium, water can be used as a direct source of prophetic inspiration, and as an effective means of supernatural action, whether it is used for purification or as a constituent of a ritual act. As a destructive power, water can be associated with the realm of chaos and death.

No coherent "water ideology" can be found in sources of prophecy, be they taken from the Hebrew Bible, Mesopotamian texts, or Greek literature, but a few recurring topics can nevertheless be identified. In biblical prophecy, water appears as the source of life and purity. Greek writers, thanks to whom we are somewhat better informed about the details of the oracular process in major Greek oracle sites, tended to associate oracles with sacred springs and the preparatory purification rites that the prophets underwent before uttering their oracles. In the case of Didyma and Claros, water also played a role as the medium of 
the divine agency, making the prophets receptive to the divine word. In biblical and other Near Eastern texts, water does not appear as a part of the oracular process, except for two letters from Mari in which men and women are given a specific drink in order to obtain oracles. In addition, some Mesopotamian texts mention the function of water as a medium of supernatural agency in connection to taking an oath. Both the Hebrew Bible and Mesopotamian prophetic texts associate water with destructive mythological powers. Rivers in particular appear as liminal spaces, the crossing of which brings about destruction to enemies, and salvation for those under divine protection. 